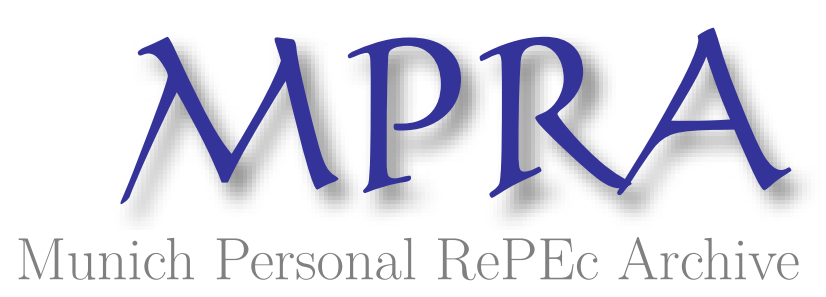

\title{
Financial Liberalization And Demand For Money: A Case of Pakistan
}

Khan, Rana Ejaz Ali and Hye, Qazi Muhammad Adnan

COMSATS Institute of Information Technology, Sahiwal. Pakistan., College of Business Management (CBM), IOBM, Karachi. Pakistan

1 March 2011

Online at https://mpra.ub.uni-muenchen.de/34795/

MPRA Paper No. 34795, posted 18 Nov 2011 15:31 UTC 


\title{
FINANCIAL LIBERALIZATION AND DEMAND FOR MONEY: A CASE OF PAKISTAN
}

\author{
Rana Ejaz Ali Khan \\ Department of Management Sciences, \\ COMSATS Institute of Information Technology, Sahiwal. Pakistan. \\ Qazi Muhammad Adnan Hye \\ Department of Economics \\ College of Business Management (CBM), IOBM, Karachi. Pakistan
}

Working Paper No. 11-2011

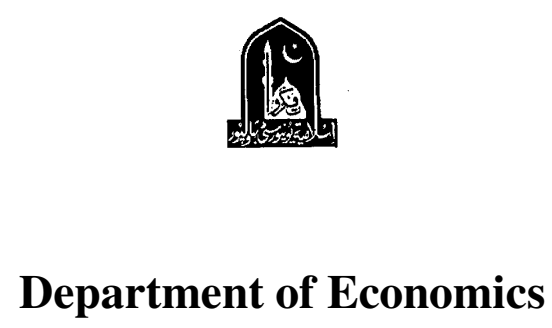

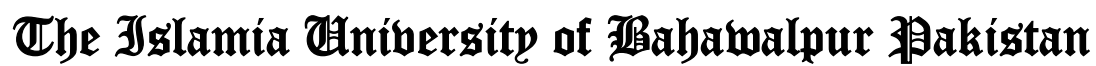

www.iub.edu.pk 


\title{
FINANCIAL LIBERALIZATION AND DEMAND FOR MONEY: A CASE OF PAKISTAN
}

\author{
Rana Ejaz Ali Khan \\ Department of Management Sciences, \\ COMSATS Institute of Information Technology, Sahiwal. Pakistan. \\ Qazi Muhammad Adnan Hye \\ Department of Economics \\ College of Business Management (CBM), IOBM, Karachi. Pakistan.
}

\begin{abstract}
Literature in economics has identified many channels through which the financial liberalization may affect demand for money. There are evidences of stability as well as instability of demand for money due to financial development for developing economies. The objective of the current study is to examine the effect of financial liberalization on demand for money in Pakistan, i.e. whether financial liberalization has affected the demand for money or not. The issue is important as stable demand for money function is a prerequisite for formulating and operating monetary policy. To achieve the objective JJ cointegration and auto regressive distributed lag (ARDL) to the cointegration is employed to estimate the long-run equilibrium relationship between broad money $\mathrm{M}_{2}$ and composite financial liberalization index along with other determinants of demand for money like gross domestic product, real deposit rate and exchange rate. In order to assess the stability of the model, the parameter constancy tests, i.e. recursive residuals, CUSUM and CUSUMSQ tests have been applied. The empirical results indicated that for broad money, there exists long-run money demand function. The financial liberalization, gross domestic product and real deposit rate positively affect the demand for money in the long as well as short-run.
\end{abstract}

JEL Classification: E41; E58; E52; O53; F31.

Keywords: Demand for money, Financial liberalization, Real deposit rate, Financial reforms, Pakistan, ARDL.

Corresponding Author's E-mail Address: ranaejazalikhan@yahoo.com

\section{INTRODUCTION}

In developed countries, the demand for narrow and broad money has become temporally unstable after continuous changes in the financial sector due to financial reforms ${ }^{1}$. Generally, the reforms increase the competition, introduce additional money substitutes, enhance the use of credit cards and electronic money transfers, increase liquidity of the time deposits and raise the international capital mobility which may make the demand for money function instable. Consequently central banks of many developed economies have abandoned money supply as a policy instrument because it makes difficult to predict demand for money with a temporally unstable function. Furthermore, the use of bank rate as the policy instrument has become attractive based on the argument that it enhances the built-in-stability of the economy. Therefore, since the late 1970 s central banks in many developed economies have abandoned using money supply as the policy instrument and switched to adjusting the rate of interest to stabilize the economy. This is consistent with 
Poole's (1970) view that the rate of interest should be targeted if demand for money is unstable $^{2}$ (see also Mishkin, 2003).

In many developing economies, following the developments in advanced countries, the central banks have started using the rate of interest as their monetary policy instrument, although there is no convincing evidence that their money demand functions have become unstable after financial reforms ${ }^{3}$. Poole (1970) argued that if demand for money is stable, central banks should use money supply as the monetary policy instrument (see also Nachega 2001). Using the rate of interest as policy instrument, in such situation accentuates instability. It is not appropriate to use interest rate as monetary policy instrument in this situation. On the other hand if money demand is unstable then velocity becomes unpredictable and the relationship between GDP, inflation and money supply growth rate becomes uncertain. Therefore it becomes important to know whether financial reforms have made money demand function stable or unstable in developing economies. Along with the issue of monetary policy effectiveness in achieving the twin goals of low inflation and sustainable growth, for seigniorage, and other crucial aspects of macroeconomic policy, the demand for money has remained a subject of continuing empirical scrutiny. The transmission mechanism of fiscal policy in a variety of economic models also significantly depends on the stability and predictability of demand for money. We will examine the relationship between demand for money and financial liberalization along with other determinants of demand for money in Pakistan. There may have been a structural change in the financial system due to liberalization leading to instability in demand for money. Such change has implications for choice of monetary policy instruments.

Our analysis to see the impact of financial liberalization on demand for money is distinguished from the previous studies particularly Hye (2009) by the following points. Hye (2009) used $\mathrm{M}_{2} / \mathrm{M}_{1}$ as a proxy of financial innovation to capture the impact of banking sector reforms on demand for money. We will take the composite financial liberalization index as a major determinant of demand for money. From the methodological point of view, we will employ JJ cointegration and autoregressive distributed lag (ARDL) approach to cointegration for long-run inference. The ARDL cointegration method has advantages over the other cointegration methods. Firstly, the ARDL model gives the robust long-run results when we work on the small sample size. Secondly, the ARDL approach is applicable whether the primary variables are entirely $\mathrm{I}(1), \mathrm{I}(0)$ or mutually integrated.

\section{CONCEPTUAL FRAMEWORK AND REVIEW OF LITERATURE}

Conceptually financial liberalization aims to improve management and resource allocation in an economy. The degree to which the financial sector in an economy actually performs its functions liberally is directly related to economic development. The financial sector is closely interrelated with the real economy (and with the conduct of its monetary and fiscal policies). The financial liberalization ultimately have a positive impact on the real economy, influencing, inter alia, the growth and structure of production and of trade. However, there may be some bad consequences of financial liberalization in the form of instability. For example, the new easier entry for financial institutions, including banks can lead to a proliferation of financial institutions. They may 
accumulate unbalanced portfolios of assets and liabilities, and unsustainable set of nonperforming loans and so many collapses as in Philippines in 1996 (Zaidi 2010:288). The two issues in this regard are of grave nature, i.e. increasing resources to currency substitution, whereby the debts and savings in local currency may be replaced by debt and savings in foreign currency. This may reduce the control of government on its own money supply and the effectiveness of any changes it tries to induce. Secondly, the expanded activity on the stock markets actually may or may not relate to new physical investment, rather than a churning of funds or a refinancing of existing debts.

The liberalization includes deregulation of deposit rates and introduction and deepening of money alternatives such as short-term (money) bonds and equities in the markets. The liberalization of interest rate is also an important feature of financial liberalization. Financial innovations being the part of financial liberalization reforms result into improvement of financial sector's ability to provide liquidity services which are alternatives to currency and demand deposits. It increases the velocity that is ultimately associated with demand for money in the economy.

The role of financial innovation or technical change in demand for money has long been theoretically considered in economic literature. Tobin (1965) argued that the creation of money substitutes make the demand for money more interest elastic. Lieberman (1977) claimed that increased use of credit, better synchronization of receipts and expenditures, reduced mail float, intensive use of money substitutes and efficient payment mechanisms tend to decrease the transaction demand for money.

The implications of financial reforms at different stages of development of an economy, on trend behavior of velocity of money can be interpreted through the views of Bordo and Jonung (1987). They opined that technical progress in the financial sector has two competing influences on the trend behavior of velocity, each dominating at a particular stage of development. During the first stage, the economy is characterized by increasing monetization. Cash and demand deposits are increasingly used for settling transactions, replacing earlier reliance on barter trade. As a result, demand for transaction balances grows more rapidly than income, and velocity is characterized by a negative trend. During the second stage, financial liberalization allows the introduction of a range of tradable and highly liquid securities. These assets substitute money as a store of value. Additionally, the technological innovation in the financial sector and the rapid transfer of funds facilitates the economizing of money balances. As a result money balances grow slower compared to the volume of transactions and velocity stabilizes or even increase over time. Hence velocity follows a U-shaped pattern. Such pattern makes difficult for modeling the demand for money function.

Empirically the literature on financial reforms has identified many channels through which the financial liberalization may affect money behavior. Increased competition between financial institutions, enhanced intermediation, increased number of banks, spur institutional advances, introduction of technology (electronic transfers, ATM, bank cards) and availability of financial instruments to money may affect lowering the demand for money as these developments make it easier to convert money substitutes into money. However, in many developing countries demand for money may rise over time because of increasing monetization (departure from barter trade in agrarian economies) of the economy and financial deepening (Melnick 1995). So, financial innovation can in principle change the demand for money in either direction (see also 
Dekle and Pradhan 1999; James 2005) ${ }^{4}$. Furthermore there can be shifts between the various categories of money. As interest rates are liberalized on time deposits, private agents may shift their assets from currency and demand deposits to time deposits, raising the velocity of narrow money, but lowering the velocity of broad money (James 2005).

The empirical literature on demand for money in Pakistan has ignored financial liberalization as a determinant of demand for money. Majority of the studies like Abe, et al. (1975), Mangla (1979), Burney and Akmal (1991), Khan (1994), Khan and Ali (1997) and Qayyum (2001) investigated demand for money by including the income, interest rate, inflation and exchange rate as explanatory variables. Hsing (2007) used the linear, log linear, and Box-Cox transform models to see the effect of GDP, domestic and foreign interest rate on demand for money. The study found a positive relationship between demand for money and GDP, and negative link between demand for money and domestic as well as foreign interest rate. Such type of traditional approaches to analyze the demand for money function is rejected by Arrau, et al. (1995). They stressed the inclusion of financial innovation as a policy variable in demand for money function. The works by Siklos (1993) and Melnick (1995 for Israel) lend support to this notion, i.e. cointegration is achieved only when a proxy for financial innovation is included as a regressor. Arrau, et al. (1995) analyzed the demand for money for ten diverse developing countries, employing various proxies for financial innovation. They used a simple model of household money demand in which the role of financial innovation is explicitly considered. The study concluded that financial innovation plays an important role in determining money demand and its fluctuation and the role of financial innovation increases with the rate of inflation.

The role of wealth in broad money demand function has been examined by Sekine (1998) taking the definition of wealth that includes financial assets along with non-financial assets, and adding it to income as a second scaling variable. The study concluded that demand for money remains stable on account of financial liberalization and wealth effect. The effect of substantial financial liberalization in ASEAN-4 countries, i.e. Indonesia, Malaysia, Singapore and Thailand on real money demand has been estimated by Dekle and Pradhan (1999). Using Johansen's Full-Information MaximumLikelihood procedure for long-run real money demand, the study found that demand equation was cointegrated. The real money and its determinants (interest rate, real income and financial innovation index as a proxy for financial liberalization) move together in the long-run. They concluded that demand for money remained stable despite financial liberalization. It was despite the fact that interest rate deregulation, greater competition in banking market and liberalization of restrictions on cross-border capital flows remained considerably higher in these countries than other developing economies.

For the estimation of stability in demand for money the use of conventional ADF test, in the presence of structural break, has been challenged by Pradhan and Subramanian (2003 for India). They used a three-step testing procedure to see the implications of financial reforms on stability of demand for money. It was consisted of estimation of cointegration relationship using full systems model. The models were reduced from systems formulation to single equation using exogeneity test. Then, cointegration between the variables allowing for the possibility of one break in the cointegration vector with unknown timings was tested. 
Parallel to the structural break, the use of the time trend as proxy of technological change in financial system is also in vogue for demand for money analysis. It measures the mean rate at which new cash management techniques have an effect on money balances, assuming technological change as exogenous to the financial sector. The inclusion of time trend in the estimation of demand for money assumes that the implementation of the new technologies reduces money demand smoothly. James (2005) has investigated the effects of financial liberalization (broadly defined to encompass financial innovations and institutional/regulatory changes) on demand for money through time trend. In the study the long-run demand for money was estimated by using the procedure developed by Pesaran, et al. (2001) and for the analysis of level relationship bounds testing approach was applied. The study concluded that financial liberalization plays a key role in determining money demand and its fluctuations.

By using cointegration and Vector Error Correction Modeling technique, the effect of globalization and financial liberalization on demand for money has been analyzed by Akhtaruzzaman (2007 for Bangladesh). The study concluded that process of globalization has no significant influence on demand for money but financial liberalization has a significant effect. The study further accomplished that currency substitution has an effective role in monetary sector, so it should be considered in monetary policy matrix. The effect of financial liberalization on demand for money in Morroco has been investigated by Zouhar and Kacemi (2008) through Johansen Maximum-Likelihood procedure. They concluded that there exists long-run money demand function. The study evidenced no-occurrence of structural break in money demand. The long-run income elasticity of $\mathrm{M}_{3}$ was estimated at 1.42 reflecting scarcity of alternative assets to hold money.

The JJ cointegration and Fully Modified Ordinary Least Squares (FMOLS) methods have been used by Hye et al. (2009) to estimate the relationship between demand for money and economic activity, interest rate, inflation, exchange rate and stock prices. They found a positive association between demand for money and stock prices but insignificant impact of exchange rate on demand for money. The study also found a positive relationship between demand for money and financial innovation in the long as well as short-run. Yu and Gan (2009) investigated the dynamics of relationship between real money balance and income, lending rates, interest rates and inflation in ASEAN-5, namely Indonesia, Malaysia, Philippines, Singapore and Thailand. The two step EngleGranger and ECM clearly showed that there exists a long-run and short-run dynamic equilibrium relationship between monetary aggregates (M1 and M2) and real income, interest rates, inflation and lending rates. Hence money demand equation for each country appears well fitting and structurally stable. The study suggested that Central Bank of these five major ASEAN countries should emphasize the narrow and broad money for monetary control to achieve their goals. However an option to a particular Central Bank to achieve either narrow or broad money is available. The bank may choose that is more applicable for setting policy target and achieving their goals. The study also indicated that in money demand model, the cost of borrowing (lending rate) plays an important role.

Dollarization is generic term for identifying the substitution of local currency from US-Dollar. Several reasons explain that phenomenon like high inflation and exchange rate depreciation may result in to rise in dollar demand for transacting, speculating or hedging against currency risk. Sanchez-Fung (2008) using PeGets 
analyzed the financial dollarization's impact on money demand in Dominican Republic that have implications for developing and operating monetary policy. The study revealed meaningful long-run relations for narrow and broad money aggregates, importantly arguing that in broad money demand function Peso-dollar interest rate differential captures the financial dollarization. The study proposed engineering a gradual move towards an interest-rate based monetary policy. Yilmaz, et. al. (2010) have also attempted to empirically analyze Kazakhstan's currency substitution as an important determinant of money growth. The consumer price index, industrial index of production as a proxy for GDP, interest rate on saving deposits, real effective exchange rate and exchange rate with Euro and Dollar were also included in the analysis of demand for money. An important finding of the study was that effective and sound monetary policy resulting in stability of domestic currency eventually causes the reversal of the currency substitution process.

Rao and Kumar (2009) used three alternative panel data methods of Pedroni, Mark and Sui and Breitung to estimate the demand for money $\left(\mathrm{M}_{1}\right)$ for a panel of 14 Asian countries. They argued that $\mathrm{M}_{1}$ is the dominant component of money supply in developing countries although alternatives $\mathrm{M}_{2}$ and $\mathrm{M}_{3}$ cannot be ruled out ${ }^{5}$. They have tested unit roots in variables with structural breaks. For the panel data cointegrating equation, the work on structural break is rare although it has some limitations. The study concluded that money demand function has been stable and financial reforms are yet to have any significant effect. Bashier and Dahlan (2011) have attempted to examine the money demand function and its stability employing CUSUM and CUSUMSQ tests in conjunction with Johansen-Juselius cointegration analysis. The empirical findings stress the existence of a positive relation between money aggregate and the level of income while the relationship was found negative for interest rate and exchange rate depreciation. Haghighat (2011) has also attempted to empirically investigate the long-run money demand function and its stability in Iran. The Johansen-Juselius cointegration test was employed to see the determinants of money demand like real income, inflation rate and exchange rate. The results have shown that money demand function has been stable and financial reforms are yet to have any significant effect. The negative sign of inflation supports the theory, i.e. people prefer to substitute physical assets for money balances. The positive sign of the exchange rate implies that as the currency of Iran depreciate, the demand for M2 increases, possibly supporting the wealth argument in literature. The study proposed that macroeconomic policies should focus not only at stabilizing the economy, but also at achieving exchange rate of the currency. The real income is positively related to M2 demand for money, that is also consistent with macroeconomic theory.

We have gone through a variety of literature having different aspects of financial liberalization and demand for money. It would be useful to take an overview of what is expected from our estimates. Firstly, we are looking for evidence on whether financial liberalization had any significant effect on demand for money or not. If it had some effects, it is to be expected that there would be evidence for some economies of scale in the use of $\mathrm{M}_{2}$. Furthermore, the response of the demand for money to the real deposit rate would be improved because of purely market based deposit rate. Therefore it is expected that financial liberalization would show a negative effect on demand for money. Secondly if reforms have created substantial number of near monies and this is a continuous process, this may lead to instability in the demand for money. This should be 
reflected by lack of well-defined long-run relationship between money and its determinants, i.e. cointegration tests might show that there is no-cointegration.

\section{PROCESS OF FINANCIAL LIBERALIZATION IN PAKISTAN}

Pakistan started the process of financial liberalization in late 1980s. In fact the liberalization was the major component of financial reforms. The objectives of the liberalization were to improve the efficiency of financial markets, formulate the marketbased and relatively more efficient monetary and credit policies and to strengthen the capital and market based financial institutions. The changes which were directed to financial market strengthening, institutional development and macroeconomic stability are briefly discussed below.

- In 1991, permission was granted to open the private domestic banks and licenses were granted to 3 foreign banks to operate in Pakistan. In later three years further 8 domestic and 3 foreign banks were established.

- The stock market of a country plays vital role in the economy by channeling resources to productive investment. The stock market reforms were started in 1991. First, the Karachi Stock Exchange (KSE) 100 index came into being and Corporate Law Authority was suspended and the Securities and Exchange Commission of Pakistan was established in 1991. In 1997 the Central Depository Company of Pakistan (CDC) was established. The trading in futures contracts was started in 2003.

- The system of credit ceilings was replaced with credit deposit ratio (CDR) in 1992. After three years the system of CDR was stopped and replaced by a market based mechanism.

- $\quad$ The system of prudential regulation was introduced in 1994.

- State Bank of Pakistan was granted autonomy in 1994, issuance of three more ordinances in 1997 further strengthen the autonomy.

- To exercise an effective indirect money policy, Open Market Operation were introduced in 1995 and now it is a major instrument of monetary policy.

- Banks were instructed to apply the system of risk-weighted capital, in line with the Board Accord. From December 31, 1997, all banks were required to maintain capital and unencumbered general resources of not less than 8 percent of their riskweighted assets.

- CAMELS framework was adopted in 1997 to ascertain the performance of banks and NBFIs on the basis of off-site and on-site surveillance.

- The interest rate deregulation was started in 1995, and completely liberalized in 1997.

- Caps on minimum lending rates of banks and NBFIs for trade and project related modes of financing were removed in 1997.

- All NBFIs were required to have themselves credit rated by State Bank of Pakistan's approved rating agency. The same become applicable for all commercial banks from June 2000.

- Lending rates on special financing schemes including locally manufactured machinery and export finance scheme were gradually raised (during 1990-2000) to eliminate the element of subsidy. 
- In order to enhance the efficiency of banking sector, the privatization of banking sector was started in 1991. The Muslim Commercial Bank (MCB), Allied Bank Limited (ABL) and Habib Credit \& Exchange Bank were privatized. The 23.2 percent share of the National Bank of Pakistan (NBP) was off-loaded in 2004-05.

- To enhance competition in the banking sector, the entry barriers in financial sector were removed in 1993.

- The banking courts were established in 1997 , to provide the legal framework of loan recoveries.

- The market based exchange rate system was introduced in 2000.

- The aim of debt management reforms was to reduce the segmentation in government debt market, rationalize the cost of raising long term government debt, establish a market-based rate of return structure for government securities and pave the way for implementation of monetary policy through instruments of indirect monetary control. A securities department was set up in the SBP to launch an auction system for public debt and develop a secondary market for government securities in 1990. In the same year auction system for treasury bills, national saving schemes (Special Saving Certificates and Special Saving Accounts) and registered and bearer certificates were introduced. To mobilize foreign exchange, the bearer instruments such as five year Foreign Currency Bearer Certificates (FCBCs) and US Dollar Bearer Certificates (DBCs), etc. were issued in January 1992. Three year FCBCs denominated in US Dollar and Pound Sterling were introduced in February 1998 and discontinued in December 2000. The outstanding stock of these certificates was reported in domestic debt, because of the Pak Rupee counterpart implications for the budget. In December 2000, the Government issued 3, 5 and 10 year Pakistan Investment Bounds (PIBs), first effectively extended the yield curve to 10 years which was further increased to 20 years.

All the components discussed above are important but for estimation it is not possible to include all of them as dummy variables in a single equation due to the problem of multicollinearity (See table-1, ordinary correlations). On the other hand some indicators cannot be dropped as it may reflect the exclusion of information about financial liberalization ${ }^{6}$. To capture the effect of maximum number of components, we have constructed the composite financial liberalization index following the Bandiera et al $(2000)^{7}$. The weights are calculated by using the principle component analysis. We used ten policy indicator in the formation of index, they are as follows: interest rate deregulation, open market operations, external account liberalization, prudential regulations, removal of entry barriers, credit controls, stock market reforms, privatization of financial institutions, non-performing loans reforms and debt management reforms. The results of principle component analysis are reported in table-1. The first principle component explains the highest level of variation (i.e. 90\%) as compared to the other linear combination of policy variables. We used first principle component value as a weight to construct financial liberalization index. In the graphical form the index has been shown in figure 1. 
TABLE-1 PRINCIPLE COMPONENT ANALYSIS

\begin{tabular}{|c|c|c|c|c|c|c|c|c|c|c|}
\hline \multicolumn{11}{|c|}{ Eigen values: $($ Sum $=10$, Average $=1)$} \\
\hline \multirow{5}{*}{$\begin{array}{c}\text { Number } \\
1.00 \\
2.00 \\
3.00\end{array}$} & \multirow{5}{*}{$\begin{array}{l}\text { Value } \\
9.00 \\
0.67 \\
0.15\end{array}$} & \multirow{5}{*}{$\begin{array}{l}\text { Difference } \\
8.32 \\
0.53 \\
0.06\end{array}$} & \multirow{5}{*}{$\begin{array}{l}\text { Proportion } \\
0.90 \\
0.07 \\
0.01\end{array}$} & \multirow{5}{*}{$\begin{array}{c}\text { Cumulative } \\
\text { Value } \\
9.00 \\
9.67 \\
9.82 \\
\end{array}$} & \multirow{2}{*}{\multicolumn{2}{|c|}{$\begin{array}{l}\text { Cumulative } \\
\text { Proportion }\end{array}$}} & & & & \\
\hline & & & & & & & & & & \\
\hline & & & & & \multicolumn{2}{|c|}{0.90} & & & & \\
\hline & & & & & \multicolumn{2}{|l|}{0.97} & & & & \\
\hline & & & & & \multicolumn{2}{|l|}{0.98} & & & & \\
\hline \multicolumn{4}{|c|}{ Eigenvectors (loadings): } & \multirow[b]{14}{*}{ PR } & \multirow[b]{14}{*}{ EB } & \multirow[b]{14}{*}{$\mathrm{CC}$} & \multirow[b]{14}{*}{ SM } & \multirow[b]{14}{*}{$\mathbf{P}$} & \multirow[b]{14}{*}{ NP } & \multirow[b]{14}{*}{ DMR } \\
\hline Variable & PC 1 & PC 2 & PC 3 & & & & & & & \\
\hline IR & 0.31 & 0.40 & 0.37 & & & & & & & \\
\hline $\mathrm{OM}$ & 0.31 & 0.40 & 0.37 & & & & & & & \\
\hline EA & 0.32 & 0.29 & -0.15 & & & & & & & \\
\hline PR & 0.32 & 0.29 & -0.15 & & & & & & & \\
\hline EB & 0.32 & 0.10 & -0.45 & & & & & & & \\
\hline $\mathrm{CC}$ & 0.32 & -0.11 & -0.43 & & & & & & & \\
\hline SM & 0.32 & -0.30 & -0.12 & & & & & & & \\
\hline $\mathrm{P}$ & 0.32 & -0.30 & -0.12 & & & & & & & \\
\hline NP & 0.31 & -0.39 & 0.36 & & & & & & & \\
\hline DM & 0.31 & -0.39 & 0.36 & & & & & & & \\
\hline \multicolumn{4}{|c|}{ Ordinary correlations: } & & & & & & & \\
\hline & IR & OM & EA & & & & & & & \\
\hline IR & 1.00 & & & & & & & & & \\
\hline $\mathrm{OM}$ & 1.00 & 1.00 & & & & & & & & \\
\hline EAL & 0.95 & 0.95 & 1.00 & & & & & & & \\
\hline PR & 0.95 & 0.95 & 1.00 & 1.00 & & & & & & \\
\hline REB & 0.90 & 0.90 & 0.95 & 0.95 & 1.00 & & & & & \\
\hline $\mathrm{CC}$ & 0.85 & 0.85 & 0.90 & 0.90 & 0.95 & 1.00 & & & & \\
\hline SM & 0.81 & 0.81 & 0.86 & 0.86 & 0.90 & 0.95 & 1.00 & & & \\
\hline POF & 0.81 & 0.81 & 0.86 & 0.86 & 0.90 & 0.95 & 1.00 & 1.00 & & \\
\hline RONPL & 0.77 & 0.77 & 0.81 & 0.81 & 0.86 & 0.90 & 0.95 & 0.95 & 1.00 & \\
\hline DMR & 0.77 & 0.77 & 0.81 & 0.81 & 0.86 & 0.90 & 0.95 & 0.95 & 1.00 & 1.00 \\
\hline \multicolumn{11}{|c|}{$\begin{array}{l}\text { Note: } \mathrm{IR}=\text { Interest rate deregulation, } \mathrm{OM}=\text { Open market operation, EAL }=\text { External account liberalization, } \mathrm{PR}= \\
\text { Prudential Regulations, } \mathrm{REB}=\text { Removal of entry barriers, } \mathrm{CC}=\text { Credit control, } \mathrm{SMR}=\mathrm{Stock} \text { market reforms, POF } \\
=\text { Privatization of financial institutions, RONPL }=\text { Reforms of Non performing loans, DMR = Debt management } \\
\text { reforms. }\end{array}$} \\
\hline
\end{tabular}


FIGURE 1. FINANCIAL LIBERALIZATION INDEX

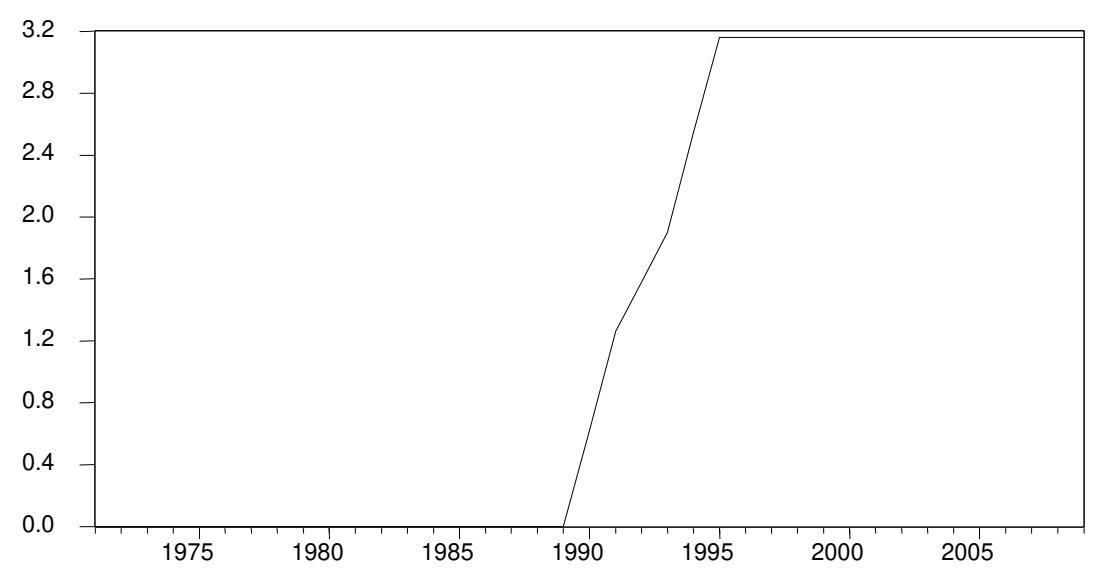

Fig-1 indicates that the country has adopted most of the financial sector reforms in between 1990 and 1996.

\section{ESTIMATION METHODOLOGY}

The financial liberalization can be captured in the money demand equation in various ways, i.e. by including dummy variables (Guncavdi, et al. 1998), a time trend (Arrau, et al. 1995; Dekle and Pradhan 1999; James 2005), institutionally related variables (Siklos, 1993) and by adjusting monetary indices (Binner, et al. 2004). We have adopted the time trend for financial liberalization. From the policy point of view, it is important to identify the measure of money for guideline in monetary policy. That measure should be the part of analysis ultimately leading to policy framework. The literature on developing countries indicates that model on narrow money works better as it reflects weak banking system and low-financial sector development in these countries. However, overtime narrow money accommodates the new instruments created as a result of evolving financial system and institutional framework. Hence we have chosen the model on broader demand for money.

We have tested the financial liberalization and demand for money (broad money $\mathrm{M}_{2}$ ) hypothesis on annual time series data ${ }^{9}$ for the years 1971-2009. The data on broad money $\left(\mathrm{M}_{2}\right)$, gross domestic product ${ }^{10}$ and real exchange rate $(\$ /$ Rs. $)$ are taken from World Bank, World development indicator and State Bank of Pakistan (various annual publications). The real deposit rate is calculated by deposit rate $e^{11}$ minus inflation rate. The financial liberalization index is constructed by using ten financial liberalization policy components to form the time series ${ }^{12}$. The informal examination of data and the graphs may be useful in giving a preliminary idea of the time series properties of the variables. 
FIGURE 2. REAL DEPOSIT RATE

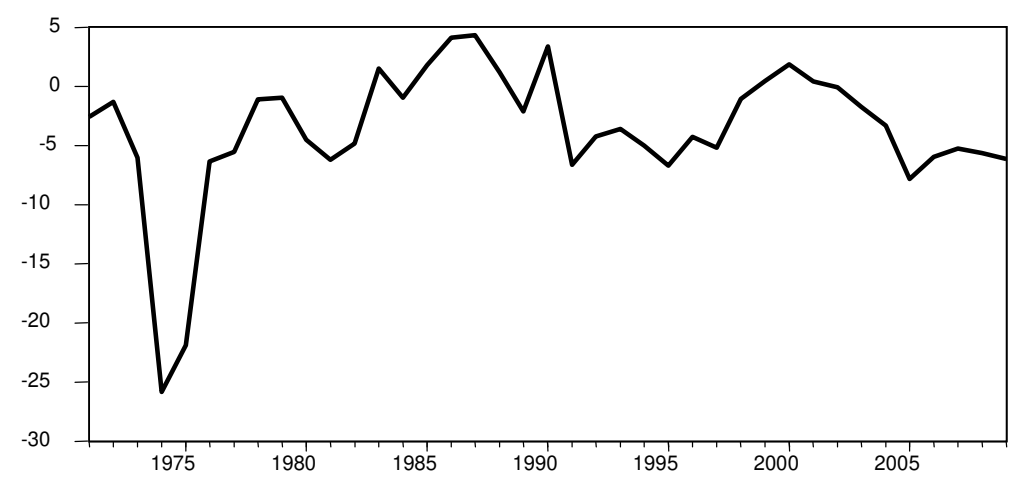

FIGURE 3. NATURAL LOGARITHMS OF REAL GROSS DOMESTIC PRODUCT AND REAL MONEY DEMAND

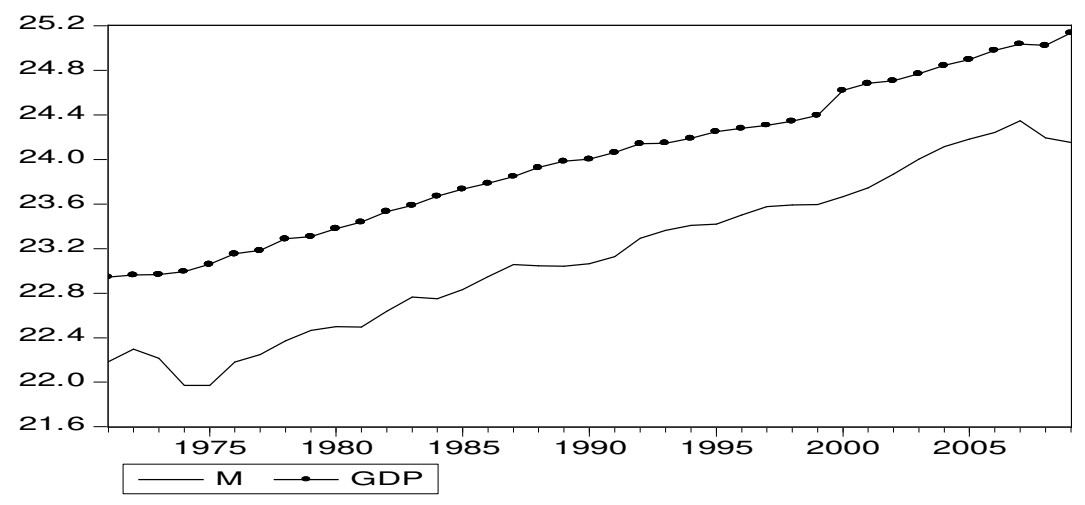

FIGURE 4. NATURAL LOGARITHMS EXCHANGE RATE \$/RS

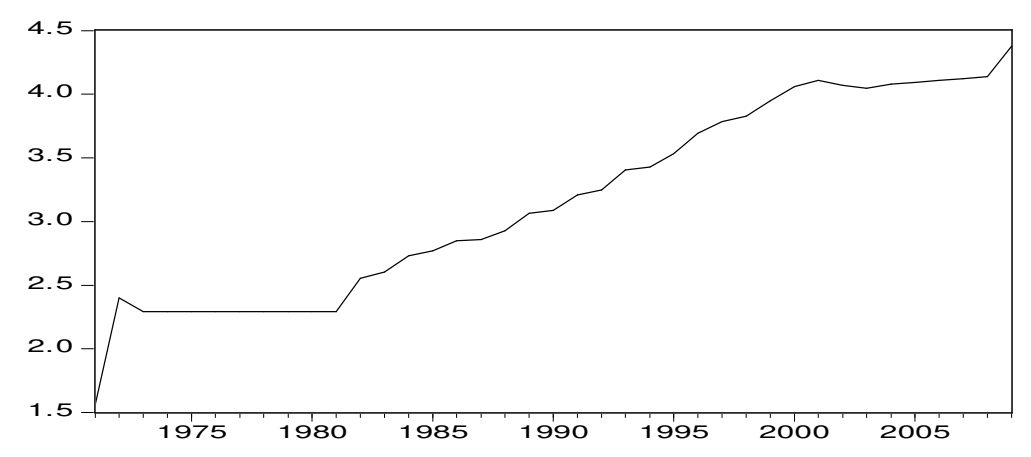


The trend of real deposit rate (RDR) is shown in fig-2. It explains that real deposit rate remained positive in 1983, 1985-1988, 1990 and 1999-2001, as a whole we can say it remained negative for the period of analysis. The demand for money and GDP have positive trends during the span of 1971 to 2009 with minor fluctuations. On the other hand exchange rate has shown positive trend but with fluctuations (see figures 3 and 4).

To investigate the association between demand for money and financial liberalization the following model has been utilized.

$\operatorname{Ln}(M)_{t}=\psi_{0}+\psi_{1} \operatorname{Ln}(G D P)_{t}+\psi_{2} F L I+\psi_{3} R D R_{t}+\psi_{4} \operatorname{Ln}(E R)_{t}+v_{t}-------(1)$

Where $M_{t}=$ Demand for money $\left(M_{2}\right), G D P_{t}=$ Gross Domestic Product,

$F L I_{t}=$ Financial Liberalization Index, $R D R_{t}=$ Real deposit rate and $E R_{t}=$ Exchange rate $^{13}$. In the economic literature, there is a general agreement that demand for money is primarily a demand for real balances. Keynes postulated three motives for holding real money balances: transaction, precautionary and speculative. Following the liquidity preference theory, economists have questioned Keynes's rationale for a speculative demand for money and have contributed to the theoretical literature by distinguishing broadly between the transaction demand for money and the asset motive (Tobin 1958; Friedman 1956). Hence empirical studies of demand for money coverage to a standard specification in which real money balances are a function of scale variables like real income, wealth or expenditure, the own rate of return on money and the opportunity cost of holding cash money as a non-interest bearing asset. We have included the real GDP as scale variable to explain the demand for money in the long-run.

The inclusion of inflation rate in demand function has been emphasized for developing countries where underdeveloped monetary and financial system and nonmarket determined interest rate exist. In this situation physical assets represent one of the major hedges against inflation and they are treated as an alternative asset in the portfolio of the non-bank public. Due to financial reforms the choice also exists between money and financial assets. To explain the behavior of the people towards substitution preference between money and financial assets we consider that real deposit rate would be more appropriate proxy for opportunity cost of holding money as compared to inflation rate.

In consideration of money demand, the appropriate opportunity cost variable is inevitable. The availability of foreign currency assets for investment implies that the variety of assets is available for portfolio diversification. The direct-currency substitution literature, which suggests portfolio shifts between domestic and foreign money, focuses on exchange rate variable, whereas, the capital mobility literature focuses on the foreign interest rate variable (James 2005) ${ }^{14}$. We have included foreign exchange rate variable to estimate money demand function (see also Akhtaruzzaman 2007 for Bangladesh). A relative increase in exchange rate of foreign currency may exert negative influence on domestic money holders to substitute foreign currency by drawing down domestic money holding.

The log lin model is used for empirical estimation in which the demand for money, gross domestic product and exchange rate have been taken in natural logarithm 
form and financial liberalization index and real interest rate without logarithm. Therefore estimation of the coefficient for interest rate would provide semi-elasticities and those of GDP and exchange rate would show elasticities. There is consensus in literature that loglinear version is the most appropriate form in such type of analysis (Sriram, 2001).

For empirical analysis it is important to determine the order of integration. There are several ways for testing the order of integration. Two generally known tests are the Dickey-Fuller test and the Augmented Dickey-Fuller test to correct autocorrelation among the error term. Perron (1989) questioned these tests for failure to take into account the structural break. We have used Perron unit root test in order to determine the order of integration. For long-run relationship between demand for money and financial liberalization we employed JJ-cointegration and autoregressive distributed lag (ARDL) approach to cointegration.

The Johansen $(1991,1995)$ cointegration test is based on $\lambda_{\text {trace }}$ and $\lambda_{\max }$ statistics. The 'Trace test' cointegration rank $r$ is as follow:

$$
\lambda_{\text {trace }}=-T \sum_{j=r+1}^{n} \operatorname{In}\left(1-\hat{\lambda}_{j}\right)
$$

On the other hand the $\lambda_{\max }$ Max-Eigen cointegrating vectors against $r+1$ is presented here as:

$$
\lambda_{\max }(r, r+1)=-T \operatorname{In}\left(1-\hat{\lambda}_{\mathrm{j}}\right)
$$

Johansen (1995) also recognized $\lambda_{\text {trace }}$ and $\lambda_{\max }$ critical values. We also employed the least cointegration technique autoregressive distributed lag (ARDL) that is proposed by Pesaran, et al. (2001). Following the James (2005) we believe that the cointegration procedures in line with Engle and Granger (1987) and Johansen (1988) which have been widely used to estimate the long-run demand for money may not be appropriate when applied to countries under financial liberalization. Standard tests for cointegration presume that the cointegraion vector is time-variant under the alternative hypothesis. This assumption, however, may be violated in the presence of financial liberalization since this process is often regarded as generating structural change (Pradhan and Subramanian 2003). Hendry and Neale (1991) have shown that (i) regime shifts/structural change can mimic unit roots in stationary autoregressive time series, (ii) each shift is very hard to detect using conventional parameter constancy tests.

We have adopted the procedure based on asymptotic critical value bounds for the Wald or F-statistics. It follows that we can investigate the existence of a long-run money demand equation in the presence of financial liberalization without needing to know if the variables included in the money demand equation are 1(1), 1(0), or mutually cointegrated $^{15}$. The vector error correction version of ARDL technique is as follows:

$$
\begin{aligned}
& \Delta \operatorname{Ln}(M)_{t}=\varphi_{0}+\sum_{i=1}^{K} \varphi_{i} \Delta \operatorname{Ln}(M)_{t-i}+\sum_{i=0}^{K} \varphi_{i} \Delta \operatorname{Ln}(G D P)_{t-i}+\sum_{i=0}^{K} \varphi_{i} \Delta \operatorname{Ln}(F L I)_{t-i}+ \\
& \sum_{i=0}^{K} \varphi_{i} \Delta \operatorname{Ln}(R D R)_{t-i}+\sum_{i=0}^{K} \varphi_{i} \Delta \operatorname{Ln}(E R)_{t-i}+\delta_{1} \operatorname{Ln}(M)_{t-1}+\delta_{2} \operatorname{Ln}(G D P)_{t-1}+ \\
& \delta_{3} \operatorname{Ln}(F L I)_{t-1}+\delta_{4} \operatorname{Ln}(R D R)_{t-1}+\delta_{5} \operatorname{Ln}(E R)_{t-1}+\mu_{t}----(2)
\end{aligned}
$$


The null hypothesis for no-cointegration between the variables in equation (2) $\left(H_{0}: \delta_{1}=\delta_{2}=\delta_{3}=\delta_{4}=\delta_{5}=0\right)$ is tested beside the alternative hypothesis $\left(H_{0}: \delta_{1}=\delta_{2}=\delta_{3}=\delta_{4}=\delta_{5} \neq 0\right)$ by using the F-test of overall level of significance. The no-cointegration hypothesis would be rejected if the estimated value of F-statistic is above the upper bound critical value and in contrast if the value of F-statistic falls below the lower bound then no-cointegration hypothesis would be accepted. An inconclusive inference can be drawn if F-statistic falls inside the upper and lower bounds.

\section{EMPIRICAL RESULTS}

In empirical analysis Perron's unit root test is used to determine the rank of integration. The test gives the parsimonious results in the small sample size. The table-2 illustrates the results of unit Perron's root test. The results indicate that all the variables, i.e. broad money (M), gross domestic product (GDP), financial liberalization index (FLI), real deposit rate (RDR) and exchange rate (ER) are integrated order one. The results support the implementation of JJ cointegration.

TABLE 2. RESULTS OF PERRON'S UNIT ROOT TEST

\begin{tabular}{cc|c|c|c|c}
\hline $\begin{array}{c}\text { Statistics } \\
(\text { Levels })\end{array}$ & Ln(M) & LN(GDP) & FLI & RDR & Ln(ER) \\
\hline$\tau_{\mathbf{T}}(\mathbf{P P})$ & -3.151 & -1.071 & -2.375 & -2.966 & -2.614 \\
$\tau_{\mu}(\mathbf{P P})$ & -0.116 & -1.917 & -0.796 & -2.069 & -1.432 \\
$\tau(\mathbf{P P})$ & 2.173 & 1.088 & 0.1176 & -1.518 & 2.106 \\
\hline Statistics $\left(\mathbf{1}^{\text {st }}\right.$ Difference) & & & & \\
\hline$\tau_{\mathbf{T}}(\mathbf{P P})$ & $-5.251^{*}$ & -3.501 & -2.847 & $-3.481^{*}$ & $-13.157^{*}$ \\
$\tau_{\mu}(\mathbf{P P})$ & $-5.391^{*}$ & -11.015 & $-2.881^{* * *}$ & $-3.302^{*}$ & $-13.533^{*}$ \\
$\tau(\mathbf{P P})$ & $-3.424^{* *}$ & -4.742 & $-2.521^{* *}$ & $-3.421^{*}$ & $-2.211^{* *}$ \\
\hline
\end{tabular}

Notes: $\tau_{\mathrm{T}}$ represents the most general model with a drift and trend; $\tau_{\mu}$ is the model with a drift and without trend; $\tau$ is the most restricted model without a drift and trend. ${ }^{*},{ }^{* *}$ and ${ }^{* * *}$ denote rejection of the null hypothesis at the $1 \%, 5 \%$ and $10 \%$ levels respectively.

The results of JJ cointegration are demonstrated in table-3. First starting with the Trace statistics, the null hypothesis of no-cointegration $(r=0)$ in the demand for money function is rejected in favour of alternative hypothesis $(r>1)$ because the $\lambda_{\text {trace }}$ is 163.095 and it is above the $10 \%$ critical value of 72.775 . In table- 3 the other hypothesis of

$\boldsymbol{r} \leq \mathbf{1}, \boldsymbol{r} \leq \mathbf{2}$ and $\boldsymbol{r} \leq \mathbf{3}$ are also rejected at $10 \%$ level of significance. Therefore we draw conclusion on the basis of $\lambda_{\text {trace }}$ that there are four cointegrating vectors among the five variables which are indicated in demand for money function. In Max-Eigen Statistic the null hypothesis of no-cointegration $(r=0)$ in favour of alternative hypothesis $(r=1)$ is rejected at $10 \%$ level of significance because the $\lambda_{\max }$ is 75.051 and it is above 
the critical value of 32.165. In lower part of table-3 the other null hypotheses $r \leq 1$ and $r \leq 2$ are rejected. Therefore we concluded stable long-run relationship among the variables.

\section{TABLE 3. RESULTS OF JJ COINTEGRATION}

\begin{tabular}{|c|c|c|c|c|}
\hline \multicolumn{4}{|c|}{ Hypothesized } & \multirow[b]{2}{*}{ Decision } \\
\hline Null Hypothesis & Alternative Hypothesis & Trace Statistic & $10 \%$ Critical Value & \\
\hline$r=0$ & $r \geq 1$ & 163.095 & 72.775 & Cointegration \\
\hline$r \leq 1$ & $r \geq 2$ & 88.043 & 50.525 & Exists \\
\hline$r \leq 2$ & $r \geq 3$ & 42.061 & 32.268 & \\
\hline$r \leq 3$ & $r \geq 4$ & 18.169 & 17.981 & \\
\hline$r \leq 4$ & $r \geq 5$ & 5.394 & 7.556 & \\
\hline Null Hypothesis & Alternative Hypothesis & $\begin{array}{c}\text { Max-Eigen } \\
\text { Statistic }\end{array}$ & $10 \%$ Critical Value & \\
\hline$r=0$ & $r=1$ & 75.051 & 32.165 & Cointegration \\
\hline$r \leq 1$ & $r=2$ & 45.983 & 26.121 & \\
\hline$r \leq 2$ & $r=3$ & 23.891 & 20.051 & \\
\hline$r \leq 3$ & $r=4$ & 12.775 & 13.905 & \\
\hline$r \leq 4$ & $r=5$ & 5.394 & 7.556 & \\
\hline
\end{tabular}

Note: $*$ and $* *$ denotes 10 percent level of significance respectively.

TABLE 4. CRITICAL VALUES FOR ARDL MODELING APPROACH

\begin{tabular}{|c|c|c|c|c|c|c|}
\hline \multirow[t]{2}{*}{$K=4$} & \multicolumn{2}{|c|}{0.10} & \multicolumn{2}{|c|}{0.05} & \multicolumn{2}{|c|}{0.01} \\
\hline & $I(0)$ & $I(1)$ & $I(0)$ & $I(1)$ & $I(0)$ & $I(1)$ \\
\hline $\mathrm{F}_{\text {III }}$ & 2.578 & 3.710 & 3.068 & 4.334 & 4.244 & 5.726 \\
\hline $\mathrm{F}_{\mathrm{IV}}$ & 3.210 & 4.294 & 3.794 & 4.986 & 5.108 & 6.494 \\
\hline $\mathrm{F}_{\mathrm{V}}$ & 2.868 & 3.782 & 3.358 & 4.365 & 4.445 & 5.615 \\
\hline$t_{v}$ & -3.13 & -4.04 & -3.41 & -4.36 & -3.96 & -4.96 \\
\hline$t_{\text {mII }}$ & -2.57 & -3.66 & -2.86 & -3.99 & -3.43 & -4.60 \\
\hline $\begin{array}{l}\text { Source: } \\
\text { Note: } \mathrm{k} \\
\text { intercept } \\
\text { restricted } \\
t_{V} \text { and }\end{array}$ & $\begin{array}{l}\text { an }(20 \\
\text { ber of } r\end{array}$ & $\begin{array}{l}\mathrm{r} \quad \mathrm{F}-\mathrm{s} \\
\mathrm{s}, F_{W} \\
\text { esents } \\
\text { he F-s } \\
\text { r testi }\end{array}$ & $\begin{array}{l}\text { and } \\
\text { nts the } \\
\text { atistic } \\
\text { of the } r\end{array}$ & $\begin{array}{l}\text { et } \\
\text { istic of } \\
\text { model w } \\
\text { vith unr } \\
\text { 2) is re }\end{array}$ & $\begin{array}{l}\text { D01) fo } \\
\text { odel wit } \\
\text { estricted } \\
\text { d interce } \\
\text { ely with }\end{array}$ & $\begin{array}{l}\text { tatistics. } \\
\text { estricted } \\
\text { cept and } \\
\text { d trend,. } \\
\text { without }\end{array}$ \\
\hline
\end{tabular}


TABLE 5. BOUND TESTING ANALYSIS

\begin{tabular}{|c|c|c|c|c|c|c|c|}
\hline & \multicolumn{3}{|c|}{$\begin{array}{c}\text { Without } \\
\text { Determintic Trends }\end{array}$} & \multicolumn{3}{|c|}{$\begin{array}{c}\text { With } \\
\text { Determintic Trends }\end{array}$} & \\
\hline Variables & Lags & $F_{\text {III }}$ & $t_{\text {III }}$ & $\mathrm{F}_{\mathrm{V}}$ & $F_{V}$ & $t_{v}$ & \multirow[t]{2}{*}{$\begin{array}{c}\text { Conclusion } \\
\mathrm{H}_{\mathrm{a}}\end{array}$} \\
\hline \multicolumn{7}{|c|}{$M=F[G D P, F L I, R D R, E R]$} & \\
\hline & $\begin{array}{l}1 \\
2 \\
3\end{array}$ & $\begin{array}{l}3.087^{5} \\
4.134^{\circ} \\
3.804^{n}\end{array}$ & $\begin{array}{l}-2.577^{5} \\
-1.158^{\circ}\end{array}$ & $\begin{array}{l}3.677^{6} \\
2.097^{\circ} \\
5.279^{\circ}\end{array}$ & $\begin{array}{l}4.348^{\circ} \\
5.685^{\circ} \\
6.082^{a}\end{array}$ & $\begin{array}{l}-3.408^{5} \\
-2.034^{a}\end{array}$ & Rejected \\
\hline
\end{tabular}

Note: $\mathrm{H}_{0}$ indicates no cointegration. ' $\mathrm{a}$ ' indicates that the statistic lies above the 0.10 upper bound, ' $b$ ' that it falls within the 0.10 bounds and 'c' that it lies below the 0.10 lower bound.

We have also estimated the long-run relationship by using cointegration approach of autoregressive distributed lag (ARDL) model. The long run relationship is investigated by using the three different scenarios (Pesaran et al. 2001:295-296) i.e. with unrestricted intercept and no trend, with unrestricted intercept and restricted trend and with unrestricted intercept and trend. The cointegration tests reject the null hypothesis of no-cointegration and provide evidence of long-run demand for money. In the next step we estimated the long-run and short-run coefficients. They are exhibited in table 6 and 7 respectively.

TABLE 6. LONG RUN COEFFICIENTS

\begin{tabular}{cc}
\hline \multicolumn{2}{c}{ Dependent Variable: $\mathbf{L n}(\mathbf{M})$} \\
\cline { 2 - 2 } Variable & ARDL coefficients \\
\hline Ln (GDP) & $0.92[15.79]^{*}$ \\
RDR & $0.01[3.09]^{*}$ \\
FLI & $0.12[2.45]^{* *}$ \\
Ln (ER) & $-0.10[-0.63]$ \\
Constant & $0.42[0.42]$ \\
\hline
\end{tabular}

Note: * and ${ }^{* *}$ denotes 1 and 10 percent level of significance respectively. T-values in the [ ]

The ARDL based long-run coefficients are shown in table-6. Results indicate that GDP, FLI and RDR positively determine the demand for money. The one unit increase in financial liberalization index and real deposit rate cause demand for money to increase by Rs. 1.03 million and Rs. 1.32 million respectively in the long-run ${ }^{16}$. This result indicates that financial reforms did not seem to have the expected effect (of Keynesian school of though). It might be due to inappropriate nature of reforms and its implementation. It may be concluded that the reforms were not efficient to control demand for money. The insignificant coefficient of exchange rate implies that phenomenon of substitution of currency might not be correctly captured by our proxy indicator. The explanation may be that currency substitution effect is not very important in explaining demand for money. It may be the possibility that economy of Pakistan is gradually emerging as an open economy but still not enough to produce a substantial currency substitution effect on demand for money. 
TABLE 7. SHORT RUN COEFFICIENTS

\begin{tabular}{cc}
\hline Variable & Dependent Variable: $\Delta(\mathbf{L n}(\mathbf{M}))$ \\
\hline$\Delta(\mathbf{L n}(\mathbf{G D P}))$ & $0.42[4.84]^{*}$ \\
$\Delta(\mathbf{R D R})$ & $0.05[3.41]^{* *}$ \\
$\Delta(\mathbf{F L I})$ & $0.06[2.91]^{* *}$ \\
$\Delta(\mathbf{L n}$ ER) & $-0.048[-0.68]$ \\
Ecm(-1) & $-0.45[-4.83]^{*}$ \\
Constant & $5.88[5.85]$ \\
\hline R-Squared & 0.58 \\
DW-statistic & 1.55 \\
\hline
\end{tabular}

Note:* and ${ }^{* *}$ denote 1 and 10 percent level of significance respectively. T-values are in the [ ]

The short-run coefficients are represented in table-7. Results indicate that the real deposit rate, financial liberalization index and gross domestic product positively influence the demand for money. The error correction terms represents the speed of adjustment from short-run disequilibrium to long-run equilibrium. It has negative sign and represents 45 percent discrepancy adjustment every year from short-run disequilibrium to long-run equilibrium.

In order to access the stability of the model, we carried the parameter constancy tests, i.e. recursive residuals, CUSUM and CUSUMSQ tests. The CUSUM test detects systematic changes in the regression coefficients while the CUSUMSQ test is used to capture sudden departure from the constancy of regression coefficients. These tests based on the unrestricted error correction models, suggest that the regression coefficients are statistically stable over the sample period. The plots of the cumulative sum and cumulative sum of squares based on the recursive residuals are shown in figure 5 and 6 respectively. They stay within the 5 percent critical boundaries that confirm the demand for money function stable.

FIGURE 5. PLOT OF CUMULATIVE SUM OF RECURSIVE RESIDUALS

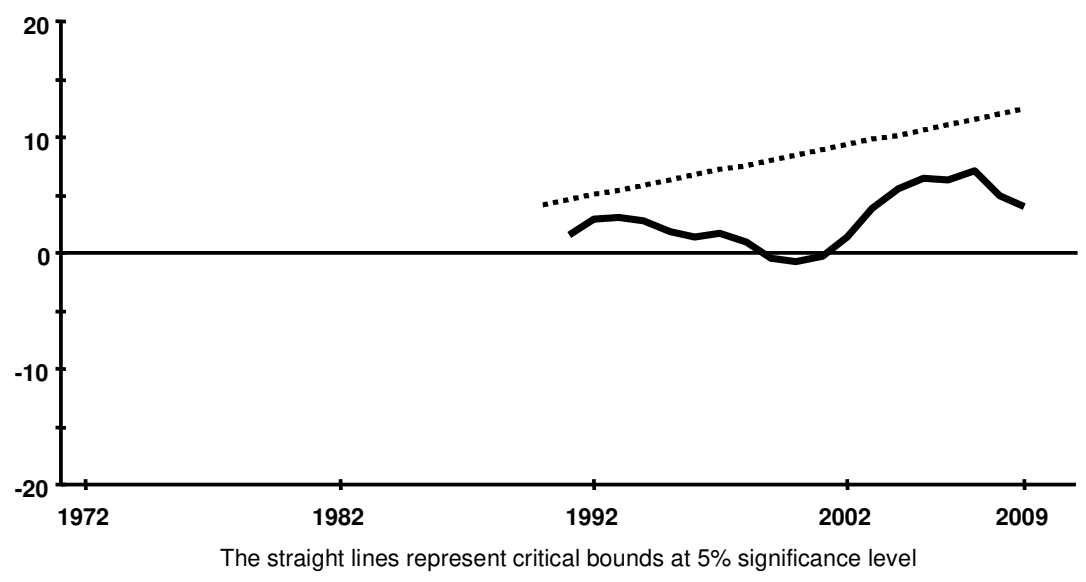


FIGURE 6. PLOT OF CUMULATIVE SUM OF SQUARES OF RECURSIVE RESIDUALS

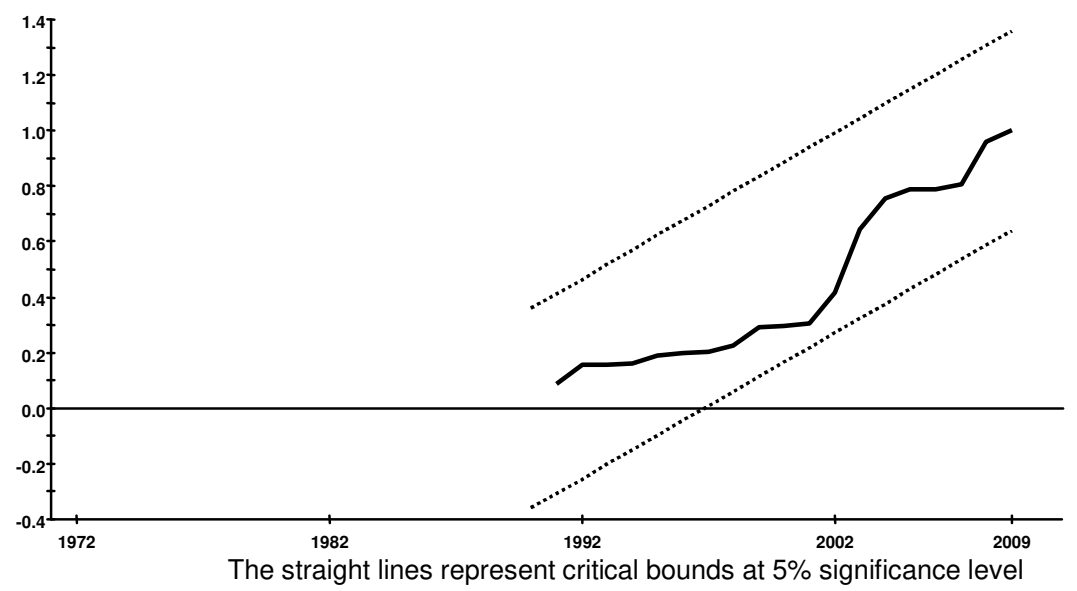

\section{CONCLUSION}

In this paper we investigated that whether financial liberalization has affected the demand for money in Pakistan or not. The issue of stability or instability of demand function is important as the predictability of the money is the cornerstone of monetary policy for targeting monetary aggregates. We employed JJ cointegration and auto regressive distributed lag (ARDL) to cointegration in order to determine the long-run relationship between broad money $\left(\mathrm{M}_{2}\right)$ and gross domestic product, financial liberalization index, real deposit rate and exchange rate. The short as well as long-run results indicate that gross domestic product, financial liberalization index and real deposit rate positively influence the long-run demand for money in Pakistan. The long-run coefficients are greater than short-run coefficients. Our results suggest that financial liberalization boosts demand for money in the long-run. One unit increase in financial liberalization index and real deposit rate causes demand for money to increase by Rs. 1.03 and Rs. 1.32 millions respectively.

The findings are important to discuss. Firstly, the GDP and real deposit rate have shown significant effect on M2. They seemed to be effective variables in explaining M2 demand for money. Secondly the positive impact of real deposit rate on demand for money implies that the effect of financial liberalization reforms remained ineffective in strengthening the role of monetary policy in Pakistan. Thirdly the currency substitution effect as captured by the real exchange rate is not significant, which implies that currency substitution effect has no role in explaining demand for money.

The cointegration tests rejected the null hypothesis of no-cointegration showing that in the long-run demand for money has become stable. The model stability tests of CUSUM and CUSUMSQ suggest that there were no structural breaks in the selected period of study. It explains that introduction of financial liberalization in Pakistan has not affected the stability of demand for money function in the long-run. One of the 
implications of the results is that financial reforms are raising the demand for money (against the Keynesian school of thought). It supports the view of structuralists and neoKeynesian that financial liberalization increases the interest rate and manufacturing cost, causing prices to boost and increase in prices remain more than the increase in interest rate. The negative real interest rate in the economy causes savings to decline and simultaneously inflation increases demand for money to finance current expenditures.

Our major finding is consistent with that of Bahmani-Oskooee and Rehman (2005), i.e. money demand function has been fairly stable in many Asian countries (including Pakistan). It is also consistent with the findings of Rao and Kumar (2009) for 14 Asian countries, Rao and Singh (2005) for India and Summers (2009) for Thailand. It implies that using the interest rate as the main monetary policy instrument is somewhat premature, inappropriate and may actually accentuate economic instability. But State Bank of Pakistan has used it in the past and recently interest rate has been applied as a monetary policy instrument to achieve the policy objectives like moderate inflation and overall economic stability. The policy makers should think over it again for the achievement of macroeconomic objectives of the policy.

\section{ENDNOTES}

${ }^{1}$ See Siklus (1993) for a number of industrial countries like Canada, Norway, Sweden and United Kingdom where demand for money function was found instable after reforms, however Hoffman and Rasche (1991) and Sekine (1998) proved stability in demand for money in USA and Japan respectively.

2 Although Rao (2007) argued that central banks should not change the interest rates as such changes have significant distributional effects. Furthermore, the recent global downturn seemed to be due to artificial lowering of interest rate by the FED in USA. If interest rates were left to be determined by the market forces, perhaps the credit bubbles, accumulation of huge toxic loans and severe downturns could be avoided.

${ }^{3}$ Bahmani-Oskooee and Rehman (2005) found that demand for money functions in several Asian developing economies (including Pakistan) by and large remained stable. Qayyum (2005) using cointegration and error correction technique while Hsing (2007) by log linear transformation concluded that there exists stability of demand for money in Pakistan. Rao and Kumar (2009) have revealed that in a number of Asian economies including Pakistan, there is strong evidence of stability in demand for money. See also, Maghyereh (2003) for Jordan; Bashier and Dahlan (2011) for Jordan and Haghighat (2011) for Iran.

${ }^{4}$ It corroborates the interpretation of Bordo and Jonung (1987).

${ }^{5}$ In the literature for stability of demand for money researchers have used different categories of money for analysis. For instance, Arrau, et al. (1995 for developing countries) M1; Sekine (1998 for Japan) $\mathrm{M}_{2}+\mathrm{CDs}$; Maghyereh (2003 for Jordan) broad money, i.e. money plus quasi money reported by IMF Financial Statistics Yearbook; Tang (2002 for Malyasia) $\mathrm{M}_{3}$; Pradhan and Subramanian (2003 for India) M1 and M3; James (2005 for Indonesia) $\mathbf{M}_{2}$; Akhtaruzzam (2007 for Bangladesh) $M_{1}$ and $M_{2}\left(M_{1}+\right.$ quasi money); Zouhar and Kacemi (2008 for Morroco) $M_{1}$ and $M_{3}$; Yu and Gan (2009 for ASEAN-5) M1 and M2; Rao and Kumar (2009 for Asian countries) $\mathrm{M}_{1}$ Yilmaz, et. al. (2010 for Kazakhstan) M2; Haghighat (2011 for Iran) M2 and Bashier and Dahlan (2011 for Jordan) M2.

${ }_{7}^{6}$ See details of implementation of components in Appendix A.

7 The value of each dummy variable of liberalization is one for the years of liberalization regime, otherwise zero. 
${ }^{8}$ Hafer and Jansen (1991) preferred broader money to evaluate the long-run economic impacts of monetary policy.

${ }^{9}$ Although for short-run relevance of parameters, that is also of interest of policy makers, the monthly time series used by Pradhan and Subramanian (2003 for India), quarterly time series used by Maghyresh (2003 for Jordan), monthly time series by Sandhez-Fung (2008 for Dominican Republic), monthly time series by Yu and Gan (2009 for ASEAN-5) and quarterly time series used by Akhtaruzzam (2007 for Bangladesh) are desirable, but the lack of such type of data for Pakistan is one reason to use annual time series data.

${ }^{10}$ GDP is measured in Pakistani rupee and M2 and GDP are divided by the consumer price index to transform them into real terms.

${ }^{11}$ The weighted Average Rates of Return on total Deposits.

${ }^{12}$ A number of proxies for financial liberalization exists in literature for money demand function. They are transaction paid by bank or ATM cards and stock market indices (see Ibrahim 2001 for Malaysia); ratio of the population to bank offices and ratio of non-bank financial assets to total financial assets. The financial liberalization index is a better measure representing composite of financial liberalization in time series, instead of outcome of financial liberalization and use of a single component.

${ }^{13}$ For the money demand function particularly reference to financial innovation and liberalization, the researchers have used a variety of explanatory variables like index of industrial production and whole sale price index (Pradhan and Subramanian 2003; Maghyereh 2003) and non-agricultural GDP and Consumer Price Index as price variable (Maghyereh 2003; Zouhar and Kacemi 2008) instead of exchange rate.

${ }^{14}$ Although studies have taken different variables, such as two interest rates, i.e. interest rate of money itself and return on rival assets (Sekine 1998); real interest rate and yield on US treasury bills (Pradhan and Subramanian 2003); foreign interest rate and domestic interest rate (Maghyreh 2003; James 2005); discount rate as proxy of interest rate (Maghyreh 2003); depreciation of exchange rate (Maghyreh 2003) and the 91-day treasury bills rate (Akhtaruzzam 2007) to take into account the opportunity cost of demand for money. London interbank offer rata is most widely used, however, a range of alternative rates like bank deposit rates, treasury bill rate, call money rates representing short-term and prime-lending rates representing the medium/long-term opportunity cost are available.

${ }^{15}$ A similar strategy is used by Tang (2002) for inflation behavior and demand for $\mathrm{M}_{3}$ in Malalysia; James (2005) for money demand function in response to financial liberalization in Indonesia.

${ }^{16}$ The antilog of financial liberalization index and real deposit rate coefficient are 1.03 and 1.32 respectively.

\section{REFERENCES}

Abe, S. et al. "The Demand for Money in Pakistan: Some Alternative Estimates". Pakistan Development Review, 1975, Vol.14, No.2, pp.249-57.

Akhtaruzzaman, M. D. "Globalization, Financial Liberalization and the Behavior of the Long-run Money Demand in the Bangladesh Economy". International Economic Journal, 2007, Vol.21, No.3, pp.465-490.

Arrau, P., J. De Gregorio., C. M. Reinhart and P. Wickham "The Demand for Money in Developing Countries: Assessing the Role of Financial Innovation". Journal of Development Economics, 1995, Vol.46, No.2, pp.317-340.

Bahmani-Oskooee, M. and H. Rehman "Stability of the Money Demand Function in Asian Developing Countries". Applied Economics, 2005, Vol.37, No.7, pp.773-792. 
Bashier, A. and A. Dalhan "Money Demand Function for Jordan: An Empirical Investigation". International Journal of Business and Social Science, 2011, Vol.2, No.5, pp. 77-86.

Binner, J. M., A. M. Gazely., S. H. Chen and T. B. Chie "Financial Innovation and Demand for Money in Taiwan: Comparative Evidence from Neutral and Vector Error-correction Forecasting Models". Contemporary Economic Policy, 2004, Vol.22, No.2, pp.213-224.

Bordo, M. D. and L. Jonung Long-run Behavior of the Velocity of Circulation: The International Evidence. 1987, Cambridge University Press, Cambridge.

Burney, N.A., and Akmal, M "Food Demand in Pakistan: An Application of the Extended Linear Expenditure System”. 1991, Journal of Agricultural Economics, Vol.42, No.2, pp.185-95.

Dekle, R. and M. Pradhan "Financial Liberalization and Money Demand in the Asian Countries". International Journal of Finance and Economics, 1999, Vol.4, No.3, pp.205-215.

Engle, R. F. and C. W. Granger "Cointegration and Error-correction Representation Estimation and Testing”. Econometrica, 1987, Vol.55, No.2, pp.251-276.

Friedman, M. The Quantity Theory of Money-A Restatement, in: Milton Friedman (ed.) Studies in the Quantity Theory of Money, 3-21. 1956, University of Chicago Press.

Guncavdi, O., M. Bleaney and A. Mckay "Financial Liberalization and Private Investment: Evidence from Turkey". Journal of Development Economics, 1998, Vol.57, No.2, pp.443-455.

Hafer, R. W. and D. W. Jansen "The Demand for Money in the United States: Evidence from Cointegration Test”. Journal of Money, Credit and Banking, 1991, Vol.23, No.2, pp.155-168.

Haghighat, J. "Real Money Demand, Income and Interest Rates in Iran: Is there a Long-run Stable Relation?”. World Journal of Social Sciences, 2011, Vol.1, No.2, pp. 95-107.

Hendry, D. F. and A. J. Neale "A Monte Carlo Study of the Effects of Structural Breaks on Tests for Unit Roots". In Hackle, P. and A. Westlong (eds.) Economic Structural Change. 1991, Springer Verlag, New York.

Hoffman, D. and R. Rasche "Long-run Income and Interest Elasticities of Money Demand in the United States". Review of Economic and Statistics, 1991, Vol.73, No.4, pp.665-674.

Hsing, Y. "Currency Substitution, Capital Mobility and Functional Forms of Money Demand in Pakistan”. The Lahore Journal of Economics, 2007, Vol.12, No.1, pp. $35-48$

Hye, Q. M. A. "Financial Innovation and Demand for Money in Pakistan". The Asian Economic Review, 2009, Vol.51, No.2, pp.219-228.

Hye, Q.M.A et al. "Relationship between Stock Prices, Exchange Rate and Demand for Money in Pakistan". Middle Eastern Finance and Economics, 2009, Issue 3, pp. 89-96.

Ibrahim, H. M. "Financial Factors and the Empirical Behavior of Money Demand: A Case Study of Malaysia". International Economic Journal, 2001, Vol.15, No.3, pp.55-72. 
James, G. A. "Money Demand and Financial Liberalization in Indonesia". Journal of Asian Economics, 2005, Vol.16, No.5, pp.817-829.

Johansen, S. "Statistical Analysis of Cointegration Vectors". Journal of Economics, Dynamics and Control, 1988, Vol.12, No.2\&3, pp.231-254.

Johansen, S. "Estimation and Hypothesis Testing of Cointegration Vectors in Gussian Vectors Autoregressive Models". 1991, Econometrica, Vol.59, No.6, pp.551-80. Johansen, S. "A Statistical Analysis of Co-integration for 1(2) variables". Econometric Theory, 1995, Vol.11, No.1, pp.25-59.

Khan A. H. and S. S. Ali "The Demand for Money in Pakistan: An Application of Cointegration and Error Correction Modeling". 1997, Savings and Development, Vol.21, No.1, pp.48-61.

Khan, A. H. "Financial Liberalization and The Demand For Money in Pakistan”. Pakistan Development Review. 1994, Vol.33, No.4, pp.997-1010.

Lieberman, C. "The Transaction Demand for Money and Technological Change". Review of Economics and Statistics, 1977, Vol.59, No.3, pp.307-317.

Maghyereh, A. "Financial Liberalization and Stability Demand for Money in Emerging Economies: Evidence from Jordan". Applied Econometrics and International Development, 2003, Vol.3, No.2, pp. 73-100.

Mangla, I.U. "An Annual Money Demand Function for Pakistan: Some Further

Results”. Pakistan Development Review, 1979, Vol.18, No.1, pp.494-499.

Melnick, R. "Financial Services, Cointegration and the Demand for Money in

Israel”. Journal of Money, Credit and Banking, 1995, Vol.27, No.1, pp.321-350.

Mishkin, F. S. The Economics of Money, Banking and Financial Markets $\left(6^{\text {th }}\right.$ Edition). 2003, Addison and Wesley, New York.

Nachega, J. C. A Cointegration Analysis of Broad Money Demand in Cameron. IMF Working Paper No. 01/26. 2001, International Monetary Fund, Washington, D.C.

Narayan, P. K. "The Saving and Investment Nexus for China: Evidence from Co-integration Tests". Applied Economics, 2005, Vol.37, No.4, pp.1979-1990.

Perron, P. "The Great Crash, the Oil Shock and the Unit-Root Hypothesis". Econometrica, 1989, Vol.57, No.6, pp.1361-1402.

Pesaran, M.H., Y. Shin and R.J. Smith "Bounds testing approaches to the analysis of level relationships". Journal of Applied Econometrics, 2001, Vol.16, No.3, pp.289-326.

Poole, W. "The Optimal Choice of Monetary Policy Instrument in a Simple Macro Model”. Quarterly Journal of Economics, 1970, Vol.84, No.2, pp.192-216.

Pradhan, B. K. and A. Subramanian "On the Stability of Demand for Money in a Developing Economy-Some Empirical Issues". Journal of Development Economics, 2003, Vol.72, No.1, pp.335-351.

Qayyum, A. "Sectoral Analysis of the Demand for Real Money Balances in Pakistan”. Pakistan Development Review, 2001, Vol.40. No.4, pp.953-966.

Rao, B. B. "The Nature of the ADAS Model Based on the IS-LM Model". Cambridge Journal of Economics, 2007, Vol.31, No.3, pp.413-422.

Rao, B. B. and R. Singh "Demand for Money in India: 1953-2003". Applied Economics, 2005, Vol.38, No.11, pp.1319-1326. 
Rao, B. B. and S. Kumar "A Panel Data Approach to the Demand for Money and the Effects of Financial Reforms in Asian Countries". Economics Modeling, 2009, Vol. 6, No.5, pp. 1012-1017.

Sanchez-Fung, J. R. Money Demand in a Dollarizing Economy: The Case of the Dominican Republic. Journal of Developing Areas, 2008, Vol.42, No.1, pp. 39-52.

Sekine, T. "Financial Liberalization, the Wealth Effect, and the Demand for Broad Money in Japan”. Monetary and Economic Studies, 1998, May 1998, pp.35-55.

Siklus, P. L. "Income Velocity and Institutional Change: Some New Time Series Evidence. 1870-1986". Journal of Money, Credit and Banking, 1993, Vol.25, No.3, pp. 377-392.

Sriram, S. S “A Survey of Recent Empirical Money Demand Studies," IMF Staff Papers, 2001, Vol. 47, No. 3, pp. 334-65.

Summer, M. Demand for Money in Thailand. Applied Economics, 2009, Vol.41, No.10, pp.1269-1276.

Tang, T. C. "Demand for M3 and Expenditure Components in Malaysia: Assessment from Bounds Testing Approach". Applied Economics Letters, 2002, Vol.9, No.11, pp.721-725.

Tobin, J. "Liquidity Preference as Behavior towards Risk". Review of Economic Studies, 1958, Vol.25, No.2, pp.65-86.

Tobin, J. "The Monetary Interpretation of History". American Economic Review, 1965, Vol.55, No.3, pp.464-485.

Yilmaz, M., Y. Oskenbayev and A. Kanat "Demand for Money in Kazakhstan 2000-2007”. Romanian Journal of Economics Forecasting, 2010, Vol.13, No.1, pp. 118129.

Yu, H. and P. Gan An Empirical Analysis of the Money Demand Function in ASEAN-5. International Research Journal of Finance and Economics, 2009, Vol.33, pp.168-178.

Karachi.

Zaidi, S. A. Issues in Pakistan Economy. 2010, Oxford University Press,

Zauhar, Y. and A. Kacemi "Financial Liberalization and Money Demand in Morocco". Working Paper No.389. 2008, Economic Research Forum.

\section{APPENDIX A}

DESCRIPTION AND IMPLEMENTATION DATA OF POLICY VARIABLES

\begin{tabular}{lc}
\multicolumn{1}{c}{ Variables } & Liberalization Year \\
\hline Interest rate deregulation(IR) & 1995 \\
Open market operation (OM) & 1995 \\
External account liberalization (EAC) & 1994 \\
Prudential Regulations (PR) & 1994 \\
Removal of entry barriers (REB) & 1993 \\
Credit control (CC) & 1992 \\
Stock market reforms (SMR) & 1991 \\
Privatization of financial institutions (P) & 1991 \\
Non performing loans (NPL) & 1990 \\
Debt management reforms (DMR) & 1990 \\
\hline
\end{tabular}

